How to cite

Aliyu, M. O., \& Kadiri, I. B. (2020). Actors in industrial relations: Growths and dwarfism of industrial relations system in Nigeria. Malaysian Management Journal, Vol. 24(July), 145-164. https://doi.org/10.32890/mmj.24.2020.8434

\title{
ACTORS IN INDUSTRIAL RELATIONS: GROWTHS AND DWARFISM OF INDUSTRIAL RELATIONS SYSTEM IN NIGERIA
}

\author{
ALIYU, MUSTAPHA OLANREWAJU* \\ KADIRI, ISMAILA BOLARINWA \\ Department of Industrial Relations and \\ Personnel Management, \\ Faculty of Management Sciences, University of Ilorin, \\ Ilorin, Nigeria.
}

Corresponding author: aliyu.om@unilorin.edu.ng

\begin{abstract}
The study focused on the actors in industrial relations and their contributions towards the growth and dwarfism of Nigeria's industrial relations system. It identified some problems which have been brought by other actors in industrial relations - the employees. In pursuit of the previously mentioned objectives, a survey research was employed. The population used for the study was 160 staff of Micheal Imoudu Institute for Labour Studies, Ilorin, Nigeria. A sample size of 114 was determined using Taro Yamani's formula (1964). The study made use of both primary and secondary data and questionnaires were administered to 114 staff but only 99 were collected, analysed and interpreted. The multiple regression analysis was used to test the hypotheses at 0.05 significant level using SPSS v.20. It was found that governments at all levels have significant impacts on the growth and dwarfism of the industrial relations system of Nigeria. The study concluded that actors in industrial relations in Nigeria affect the growths and dwarfisms of Nigeria's industrial relations system and it is recommended that further research be extended to other industries such as construction, agriculture and telecommunication.
\end{abstract}


The study can also be used as guidelines for human resource aficionados and industrial relations experts.

Keywords: Actors in industrial relations, industrial relations, growth, dwarfism, employers' association, trade union, Nigeria.

Received: 17/8/2019 Revised: 21/10/2019 Accepted: 25/6//2020 Published: 30/8/2020

\section{Introduction}

In Professor John Thomas Dunlop's work entitled, Industrial relations system (1958), the term 'actors' in industrial relations enjoyed prominence. These actors are now recognised as participating in the labour market balance of competing interests (Rose, 2008). These actors consist of employers and their associations, the employees and their unions and the governments and its agencies (Marsh, Evans \& Garcia, 1971). Employers are the business owners, the business controllers, the business managers and the business overseers. The employer is that individual or group of individuals who contributed property in a business venture with the strength of making a return profit (Fajana, 2006). Employers have alliance that expecting employees' sincerity, punctuality, development of new skills, hardwork, readiness to provide extra hours as and when required. To the extent that some employers belong to association to provide a single voice (Akintayo \& Adeyeye, 2012).

The industry's main emphasis in industrial relations is seen as one that stresses the establishment in good relationships, mutual respect within an industrial organisation (Adeniji, 2015). The concept of growth connotes an increase in size, value, quantity, number or a state of expansion or enlargement. Here, growth focuses on the developmental aspects of the actors, individually, towards the industrial relations system in Nigeria. Before the colonial era to the post-colonial era, what changes have the industrial relations system put in place in Nigeria? What impact does the relationship which subsists among them make towards the society? All these and other questions need some answers.

To bolster more on the apparent problems Nigeria's industrial relations system still encounters; as at the last quarter of the year 2017, some state governments were yet to pay-off their staff' salaries. This backlog of salaries has a huge and horrific effect on industrial relations system in the country. It is very important, also, to identify some problems which have been brought by another set of actors in industrial relations - the employees. Labour union in Nigeria has made industrial relations system hideous and tedious to swat. 
Adebiyi (1985) identified that most union leaders used trade unionism for their political and egotistical benefit without much regard for the members' welfare. More so, because of inter-conflict between unions, there was no unity between single workers. Historically, these were some of the reasons forthe ban on some union leaders from ever again participating in Nigeria's trade unionism (Olufemi, 2018; Yesufu, 1984). The employers have detestably impacted Nigeria's industrial relations system this could be characterised in terms of poor pay, inadequate working facility, irregular/absence of motivation, etc.

The main objective of the study is to explore the actors in industrial relations and the growths and dwarfism of the industrial relations system in Nigeria. The specific objectives are several, which include (i) to examine the influence of employers on the growth and dwarfism of the industrial relations system of Nigeria, (ii) to explore the impact of employees on the growth and dwarfism of the industrial relations system of Nigeria and (iii) to determine the effect of government on the growth and dwarfism of the industrial relations system of Nigeria.

\section{Literature Review}

In contemporary industrial society, the idea of industrial relations constitutes one of the most fragile and dynamic problems (Ayantunji \& Ayantunji, 2016; Beckman \& Jega, 1998). The advent of 'Manufacturing Revolution' (Pradip, 2015) explicitly attributes this trend to a new hierarchical manufacturing setup. The term industrial relations refers to relationships within the industry between the management and the workers. Northrup (2018) defined industrial relations as the management method of reaching a collective bargaining agreement or labour contract with one or more unions and then implementing it. The government cannot remain a silent and powerless spectator in the economic welfare with an ever-increasing focus on the welfare dimension of governmental intervention (Northrup, 2018).

Fajana (2005) described industrial relations as encompassing any imaginable aspect that affects the management of labour (human resources), including government activities or its agents in managing such a workforce. Fashoyin (1988) calimed that industrial relations are not restricted to what happens between management and employees in public and private enterprises, nor are they restricted to the enforcement of labour laws and collective bargaining. The industrial relationship refers to the pattern of contact or partnership 
between the employer or management on the one hand and workers or labour unions on the other, including government actions in regulating and managing the system of industrial relations (Ayogu, 2016).

\section{Actors in the Industrial Relations System}

\section{Employers and their associations}

Employers and their associations expect good and other pecuniary profits in return for their investments in raw materials and other resources for the production of goods and services provided by them (Oyelekan \& Mojirade, 2013). Employers are saddled with the responsibility of establishing suitable policies and procedures within the organisation for handling disciplinary issues (Abdullahi, 2014). The employer is the who, in a business venture, has contributed his/her property in return for some income (Fajana, 2000). New industries are promoting manager-managed interactions (Praveen, 2015). For a public corporation or state parastatal, labour force control is typically assigned by a board of directors to a hierarchy of managers. A closer look at the employers of Nigeria demonstrates this argument mentioned in the last paragraph. The employers based in Nigeria include both indigenous and international employers (Fajana, 2000). Indigenous or local employers are less vulnerable to the threats posed by workers and government whereas the international employers are more vulnerable to these threats by both staff and government.

As noted by Marx, the main objective of every employer is the maximisation of production through employees to the long working duration at a cheap cost (Adeniji, 2015). Marx theorises that if employers want to survive a stiff competition, they must treat their labour force as a controllable resource (Richardson, 2013). Apart from increasing the level of productivity, the majorly and generally accepted motive of every business owner even in a developing country like Nigeria is to maximise profit. Consequently, the incessant involvement of government in industrial relations in Nigeria has induced employers to seek common platform either to mitigate government labour policy or to guide against unfair treatment of any of its members (Shalev, 2010). This indicates that politico-economic factors could be very important, as well as the power of other parties in industrial relations

\section{Employees and their Unions}

To exchange for their work, workers and their labour unions demand bountiful salaries and other desirable working conditions (Oyelekan \& Mojirade, 
2013). Employees and their unions have learned to make themselves secure against ills over which they believed to have little control (Praveen, 2015). Therefore, the basic aim of trade unions is to take care of the interests of their members, provide security programs and raise members' morale as well as maintain good ties between staff and management. Besides, the trade unions have the prerogative of demanding the participation of workers in management. The tasks of the labour unions are also to provide financial help to its members, to contribute to the reduction of industrial conflicts and to achieve improved working conditions for its members (Okaka, 2005).

\section{Government and its agencies}

To exchange for their services, the government and its agencies expect tax and orderliness to provide the enabling atmosphere for the development of goods and services to an organisation (Oyelekan \& Mojirade, 2013). The degree of government intervention in matters relating to industrial relations is determined by the development of the economic stage. For example, in a developing economy like Nigeria, work stoppages to settle claims have more serious implications than in a developed economy. Likewise, a free-market economy leaves the parties free to settle their relations through strikes and lockouts but involvement is required in other systems with varying degrees with the government to help established sound labour relations.

\section{Growth of Industrial Relations System in Nigeria}

In the 1960s, more sophisticated organisational structure and management processes were needed to manage them as organisations grew larger (Enenya, 2013). Managing employees in the organisation became extremely difficult to perform; this gave rise to deploy expatriates who can handle this difficulty as it relates to human resource. Hence, the human resource department was created in some organisations. The role of the human resource in this modern-day involves the development of jobs to increase motivational content, the administration of management through goals programs and training, recruiting, selection, hiring, compensation, therapy, labour relations and a host of innovations (Fajana, 2000).

The development of industrial relations and personnel functions in work organisations is a reaction of business owners (employers) to the increasing unhappiness of the trade union and the state's activities (Enenya, 2013). The industrial activities of COLA trade unions, with a high potential political orientation, were the major factor influencing the adoption of personnel management as a function to be managed by specialists (Fajana, 2000). 
Before trading union legal recognition in 1938, the control of personnel and labour relations were limited to record-keeping and hiring. In the 60 s, expatriates covered most of the personnel positions which the unions thought were workers' oppressors. Later, business owners had to embark on that function's Nigerianisation. The Nigerianisation process absorbed trade union leaders into the position of staff managers (Fashoyin, 1980). Many of the employers viewed the staff manager's position as a pacifier of unionistswhilst others viewed it as the edifier of the union leaders' authorship of the dispute (Emiola, 1979).

Also, the situation changed with independence, with the recruitment of recent laureates. The emphasis now is on how to make those sets of actors responsible for industrial relations and make a remarkable contribution to their economies. In modern times, through the employers' association - Nigerian Employers Consultative Association (NECA) Committee on Industrial Relations, Education and Training, company owners or employers control various aspects of the role of staff and industrial relations (Enenya, 2013).

\section{Dwarfism of Nigeria's Industrial Relations}

Nigeria's system of industrial relations has been in a short-state that restrains from growth rather than backwardness; this leads to the shortcomings of the system in Nigeria (Ubeku, 1983). The actors in Nigeria's industrial relations system are conversant and stable with the strike. The issue of the strike in Nigeria's industrial relations system has been for a very long time and has not been carefully treated and enhanced. That has caused incessant backwardness of dwarfism to the system of industrial relations in Nigeria. History reveals to every Nigerian that the first nation-wide strike erupted before independence on June 22 1945. The The activist, christened as $\mathrm{Mr}$ Michael Imoudu, remained the vanguard of the strike (Fajana, 2007). The advent of this strike brought more hostility and hardship to the labour and other Nigerian citizens.

Nigeria's industrial relations system has also experienced a state of a drawback because of the disunity it has caused in the industry among those actors in Nigeria's industrial relations system (Fajana, 2007). This could be explained since the legal creation of the trade union ordinance of 1938. This ordinance encouraged the creation of a labour union in any organisation. Hence, segregating the employees from the employers which coin to disunity in the industry. Nigeria's industrial relations system presents a narrow view of work from the employees rather than sectional views from the employees. 
This is resulted by having different associations and unions formed and joined by the major actors in Nigeria's industrial relations system. Instead of seeing things in a similar view, the actors would see it in diverse views because of the disunity between them.

\section{Theoretical Framework}

Scholars from diverse disciplines have discussed the concept of industrial relations. Their theoretical contributions have one way or the other impacted the forwardness and backwardness of industrial relations, especially in Nigeria. Some of the scholars believed that the industry is centrally concentrated, while some believed it is pluralised and some other views were quite indifferent. Some of the industrial relations theories whih are related to the study are listed and explained below.

\section{The Marxist Theory of Industrial Relations}

According to Marxists, industrial relations have pluralistic attributes, are being politicised, and tend to be viewed as the survival of the fittest league. For Marxist, industrial and workplace relations may only be understood as part of the wider study of capitalist society, in particular, the social relations of production and the dynamics of capital accumulation. The Marxist approach is mainly geared towards the historical nature of the power relationship between capital and labour. The application of Marxian theory as it relates to industrial relations today comes from later Marxist scholars rather than from Karl Marx's works directly (Ogunbameru, 2004). Karl (1950) had not written on the subject of industrial relations in a simplified phrase but suggested that his definition of capitalism may also contribute to a play based in industrial relations settings. The Marxist point of view about labour relations is considered to be imperfect and not to any degree, normative (Cox, 1999). This is because his view considers only the owner to be the worker and the capitalist. The complexity of industrial relations is broader than that of Marx's duo; this makes his interpretation incomplete and not normative (Flanders, 1975).

\section{The Pluralist Theory of Industrial Relations}

The pluralism theories emerged in the mid-sixties and early seventies when Britain was experiencing a rapid revival of industrial conflict. The pluralist theory to industrial relations was offered more contemporary ideas by some erudite British such as Flanders and Fox (1975). Conflict is an inherent part 
of the industrial system according to Flanders (1968). He emphasised the need for a structured collective bargaining structure as a means for resolving disputes. In the employment relationship, conflict is accepted and recognised as endemic and regulated by representative organisations, institutions and processes (Salamon, 2000). Trade unions are seen as legitimate employee representatives. Fox (1973) provided a distinction between two distinct facets of the working-management relationship. The first relates to the market relationship, which concerns the terms and conditions under which labour is employed (Gill, 2007). This relationship is essentially economic and is focused on contracts between the parties. The second dimension concerns the management's handling of labour, the essence of the relationship, the union-management relations, the balance of power within the organisation and the union's involvement in joint decision-making (Gill, 2007).

\section{Dunlop's System Theory of Industrial Relations}

Dunlop (1958) viewed the system of industrial relations as certain actors at any time in its development, an ideology that binds the system of industrial relations together, and a set of rules created to govern the actors in the workplace and the working community. Three sets of independent variables are available: the system's 'actors,' 'context' and 'ideology.' The Systems Model is generally credited to John T. Dunlop, a widely regarded American Professor of Labour Economics (Christopher \& Okwy, 2015). Dunlop built his theoretical approach to industrial relations based on a system definition and was strongly influenced by Parsons' prior work (Fajana, 2000). Dunlop specifically based his model on the Parsons social structure, which took on an implicit tendency against order and harmony (Fajana, 2000).

The Marxist Theory of Industrial Relations (1950), however, was not sufficient to explain the issues surrounding industrial relations actors. The Pluralist Theory of Industrial Relations (1975) on pluralism was developed to support the earlier theory while Dunlop's Structure Theory of Industrial Relations (1958) was adopted as the most known and accepted theory of industrial relations. It is due to its scope, substantiality, and a broad-based integrative model that seeks to provide analytical tools to interpret and gain the widest possible understanding of the acts. The practices of industrial relations and to explain why specific rules are established in a particular system of social, industrial relations, distinct from but overlapping, the economic and political subsystem. The theoretical framework of the study is shown in Figure 1. 


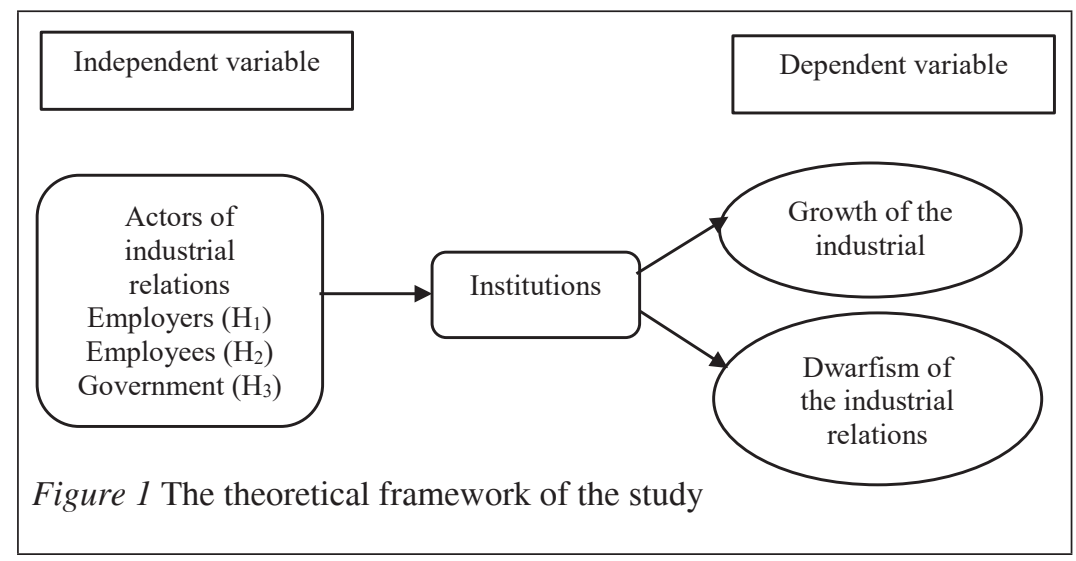

The conceptual framework of the study shows an independent variable of employers, employees and governments which described by the dependent variables of growths and dwarfism of the industrial relations system. When there is a harmonious relationship among the actors, it may promote effective industrial relation system and vice versa. Sequel to the theoretical and conceptual framework developed for this study. The following research hypotheses were formulated in null forms to guide the study;

$\mathrm{H}_{1}$ : Employers or their associations have no impact on the growth and dwarfism of the industrial relations system of Nigeria.

$\mathrm{H}_{2}$ : Employees or their unions have no impact on the growth and dwarfism of the industrial relations system of Nigeria.

$\mathrm{H}_{3}$ : Government has no impact on the growth and dwarfism of the industrial relations system of Nigeria

\section{Methodology}

This research is an empirical study, and a research survey technique was employed using a questionnaire was used to collect the data and investigate the relationship between the dependent variable and independent variables. The survey technique was chosen because it reduces census-related costs and time, and is capable of producing quantitative data. The population was obtained from the Micheal Imoudu Institute for Labour Studies. The number of population is 160 . It consists of both permanent and casual workers as well as both superior and rank and file workers. 
The study used a simple random sampling technique and this was achieved by giving every member of the population an equal chance of being included in the sample. In determining the sample size for this study, Yamani's (1964) statistical formula was applied.

$\mathrm{n}=\mathrm{N} / 1+\mathrm{N}(\mathrm{e})^{2}$

where; $\mathrm{n}=$ Sample size

$\mathrm{N}=$ Total number of the population studied

$\mathrm{E}=$ Error term or \% level of significant or margin of tolerable error

The researcher chooses a $5 \%$ level of significance or margin of tolerable error. Since $N=160, e=0.05$ or $5 \%$, so $n$ is equal 114 .

$\mathrm{n}=160 / 1+160(0.05)^{2}$

$\mathrm{n}=160 / 1.4$

$\mathrm{n}=114.285714 \quad \mathrm{n}=114$ (approx.)

The multiple linear regression was used in the estimation of the model. Multiple linear regression has three independent variables [employers (YER); employees (YEE) and government (GOV)] and a dependent variable [growths (GRW) and dwarfism (DWF)]. The model are shown by Equation (1) and Equation (2).

$$
\begin{aligned}
& G R W_{i}=\beta_{0}+\beta_{1} Y E R_{i}+\beta_{2} Y E E_{i}+\beta_{3} G O V_{i}+\varepsilon_{i} \\
& D W F_{i}=\gamma_{0}+\gamma_{1} Y E R_{i}+\gamma_{2} Y E E_{i}+\gamma_{3} G O V_{i}+\varepsilon_{i} \\
& \gamma_{i}, \beta_{i}=\text { coefficients, } i=0,1,2,3 \\
& \varepsilon \quad=\text { error terms }
\end{aligned}
$$

\section{Data Analysis and Results}

Table 1 shows that 64 respondents representing 64.6 percent were male, 35 respondents representing 35.4 percent were female. The implication of this is that the nature of activities occurring in Micheal Imoudu National Institute for Labour Studies were for both male and female individuals, especially in the area of ongoing the growth and dwarfism of Nigeria's industrial relations system in the country. The table further indicates that 29 respondents representing 29.3 percent were between the ages of 18-28, 31 respondents representing 31.3 percent were between ages 29-39, 39 respondents which represent 39.4 per cent were between the age of 40-50. It shows that majority 
of the respondent are within the ages of 40 and 50 years, and it implies that they were capable of providing relevant information useful for this study. Similarly, Table 1 shows that 43 respondents representing 43.4 percent were single, 46 respondents representing 46.5 percent were married, 5 respondents $(5.1 \%)$ were widow/er, and 5 respondents $(5.1 \%)$ were divorced. The implication is that the institution has a high degree of employees who are matured enough and can work successfully in a team.

Table 1

Socio-demographic Characteristics of the Respondents

\begin{tabular}{|c|c|c|}
\hline Socio-demographic Characteristics & Frequency & Per centage $(\%)$ \\
\hline \multicolumn{3}{|l|}{ Gender: } \\
\hline Female & 64 & 64.6 \\
\hline Male & 35 & 35.4 \\
\hline Total & 99 & 100 \\
\hline \multicolumn{3}{|l|}{ Age (Years): } \\
\hline less than 25years & 29 & 29.3 \\
\hline $26-35$ years & 31 & 31.3 \\
\hline $36-45$ years & 39 & 39.4 \\
\hline Total & 99 & 100 \\
\hline \multicolumn{3}{|l|}{ Marital Status: } \\
\hline Single & 43 & 43.4 \\
\hline Married & 46 & 46.5 \\
\hline Widowed & 5 & 5.1 \\
\hline Divorced & 5 & 5.1 \\
\hline Total & 99 & 100 \\
\hline \multicolumn{3}{|l|}{ Educational Qualifications: } \\
\hline OND/NCE & 29 & 29.3 \\
\hline Bachelor Degree/HND & 29 & 29.3 \\
\hline Master's Degree & 32 & 32.3 \\
\hline $\mathrm{PhD}$ & 9 & 9.1 \\
\hline Total & 99 & 100 \\
\hline \multicolumn{3}{|l|}{ Work Experience (Years): } \\
\hline$<2$ years & 39 & 39.4 \\
\hline $3-5$ years & 22 & 22.2 \\
\hline $6-10$ years & 24 & 24.2 \\
\hline 11 years and above & 14 & 14.1 \\
\hline Total & 99 & 100 \\
\hline
\end{tabular}


Also in the table, 29 respondents representing 29.3 per cent were NCE/ND or equivalent, 29 respondents representing 29.3 percent were BSC/HND holders or equivalents, 32 respondents representing 32.3 percent were MBA/MSC holders or equivalents while nine respondents (9.1\%) specified others. The fact that most of the staff was holding masters or equivalents or additional qualifications which shows that they have what it takes to comprehend knowledge of the growth and dwarfism of Nigeria's industrial relations system in the country. Finally, the table reveals that 39 respondents representing 39.4 per cent have work experience below five years, 22 respondents representing 22.2 percent were within the range of six to ten years work experience, 24 respondents representing 24.2 percent were within the range of eleven to fifteen years work experience, 14 respondents representing 14.1 per cent have fifteen years and above work experience. Hence, the above analysis indicates that majority of the staff under consideration were within the range of zero to five years work experience and therefore, they have a sense of belongings and current information needed to justify the analysis of the growth and dwarfism of Nigeria's industrial relations system in Nigeria.

\section{Respondents' Views on Growth and Dwarfism of Industrial Relations System}

Data from Table 2 shows the opinions of the respondents on their agreement level on the issues relating to the actors in industrial relations, the growth and dwarfism of the industrial relations system in Nigeria.

Table 2

Respondents' Views on Growth and Dwarfism of Industrial Relations System

\begin{tabular}{|c|c|c|c|c|c|c|c|c|c|c|}
\hline \multirow{2}{*}{$\begin{array}{l}\text { Respondents' } \\
\text { Views on } \\
\text { Growth and } \\
\text { Dwarfism } \\
\text { of Industrial } \\
\text { Relations } \\
\text { System }\end{array}$} & \multicolumn{2}{|c|}{$\begin{array}{l}\text { Strongly } \\
\text { Disagree }\end{array}$} & \multicolumn{2}{|c|}{ Disagree } & \multicolumn{2}{|c|}{ Undecided } & \multicolumn{2}{|c|}{ Agree } & \multicolumn{2}{|c|}{$\begin{array}{l}\text { Strongly } \\
\text { Agree }\end{array}$} \\
\hline & 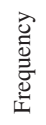 & $\begin{array}{l}\overrightarrow{0} \\
0 \\
\dot{0} \\
\dot{0}\end{array}$ & 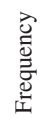 & $\begin{array}{c}\overrightarrow{0} \\
0 \\
\dot{0} \\
\overrightarrow{0}\end{array}$ & 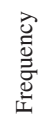 & $\begin{array}{l}\overrightarrow{0} \\
0 \\
\dot{0} \\
\overrightarrow{0}\end{array}$ & 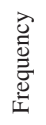 & 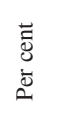 & 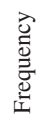 & $\begin{array}{l}\vec{\Xi} \\
\bar{\Xi} \\
\vec{\Delta} \\
\text { Q }\end{array}$ \\
\hline $\begin{array}{l}\text { Employers } \\
\text { interaction with } \\
\text { subordinates } \\
\text { cover } \\
\text { organisation }\end{array}$ & 19 & 19.2 & 57 & 57.6 & 10 & 10.1 & 3 & 3.0 & 10 & 10.1 \\
\hline $\begin{array}{l}\text { Employers } \\
\text { association } \\
\text { bargains with } \\
\text { employees }\end{array}$ & 29 & 29.3 & 47 & 47.5 & 12 & 12.1 & 9 & 9.1 & 2 & 2.0 \\
\hline
\end{tabular}

(continued) 
Malaysian Management Journal Vol. 24, July 2020 145-164

\begin{tabular}{|c|c|c|c|c|c|c|c|c|c|c|}
\hline \multirow{2}{*}{$\begin{array}{l}\text { Respondents' } \\
\text { Views on } \\
\text { Growth and } \\
\text { Dwarfism } \\
\text { of Industrial } \\
\text { Relations } \\
\text { System }\end{array}$} & \multicolumn{2}{|c|}{$\begin{array}{l}\text { Strongly } \\
\text { Disagree }\end{array}$} & \multicolumn{2}{|c|}{ Disagree } & \multicolumn{2}{|c|}{ Undecided } & \multicolumn{2}{|c|}{ Agree } & \multicolumn{2}{|c|}{$\begin{array}{l}\text { Strongly } \\
\text { Agree }\end{array}$} \\
\hline & 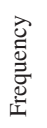 & $\begin{array}{l}\overrightarrow{0} \\
\text { ठ } \\
\dot{0} \\
0\end{array}$ & 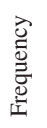 & $\begin{array}{l}\ddot{\bar{\Xi}} \\
\dot{0} \\
\text { ¿ }\end{array}$ & 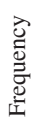 & $\begin{array}{l}\overrightarrow{0} \\
0 \\
0 \\
0\end{array}$ & 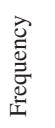 & $\begin{array}{l}\overrightarrow{0} \\
0 \\
0 \\
0\end{array}$ & 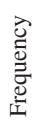 & $\begin{array}{l}\overrightarrow{0} \\
0 \\
\dot{0} \\
2\end{array}$ \\
\hline $\begin{array}{l}\text { Fair distribution } \\
\text { of pay is made } \\
\text { by the employer }\end{array}$ & 20 & 20.2 & 51 & 51.5 & 17 & 17.2 & 5 & 5.1 & 6 & 6.1 \\
\hline $\begin{array}{l}\text { Stringent } \\
\text { policies } \\
\text { principles } \\
\text { promulgated by } \\
\text { employer }\end{array}$ & 24 & 24.2 & 50 & 50.5 & 10 & 10.1 & 5 & 5.1 & 10 & 10.1 \\
\hline $\begin{array}{l}\text { Trade union } \\
\text { helps everyone } \\
\text { in the country to } \\
\text { acquire desires }\end{array}$ & 13 & 13.1 & 57 & 57.6 & 9 & 9.1 & 8 & 8.1 & 12 & 12.1 \\
\hline $\begin{array}{l}\text { The association } \\
\text { represents } \\
\text { the interest of } \\
\text { everyone }\end{array}$ & 16 & 16.2 & 47 & 47.5 & 18 & 18.2 & 11 & 11.1 & 7 & 7.1 \\
\hline $\begin{array}{l}\text { The use of } \\
\text { strike is the best } \\
\text { instrument that } \\
\text { helps employees }\end{array}$ & 31 & 31.3 & 15 & 15.2 & 15 & 15.2 & 18 & 18.2 & 20 & 20.2 \\
\hline $\begin{array}{l}\text { Labour } \\
\text { union helps } \\
\text { in boosting } \\
\text { the level of } \\
\text { interaction }\end{array}$ & 40 & 40.4 & 32 & 32.3 & 3 & 3.0 & 5 & 5.1 & 19 & 19.2 \\
\hline $\begin{array}{l}\text { Policies made } \\
\text { by governmen. } \\
\text { has encouraged } \\
\text { peace }\end{array}$ & 27 & 27.3 & 32 & 32.3 & 16 & 16.2 & 0 & 0 & 24 & 24.2 \\
\hline $\begin{array}{l}\text { Government } \\
\text { organises } \\
\text { platforms where } \\
\text { parties are } \\
\text { celebrated }\end{array}$ & 12 & 12.1 & 39 & 39.4 & 18 & 18.2 & 8 & 8.1 & 22 & 22.2 \\
\hline $\begin{array}{l}\text { External laws } \\
\text { strengthen the } \\
\text { relationship } \\
\text { among parties }\end{array}$ & 19 & 19.2 & 27 & 27.3 & 20 & 20.2 & 4 & 4.0 & 29 & 29.3 \\
\hline $\begin{array}{l}\text { Trade union } \\
\text { needs no } \\
\text { support from } \\
\text { the government }\end{array}$ & 14 & 14.1 & 13 & 13.1 & 11 & 11.1 & 29 & 29.3 & 32 & 32.3 \\
\hline
\end{tabular}

$\mathrm{H}_{1}$ : Employers or their associations have no impact on the growth and dwarfism of the industrial relations system of Nigeria. 
The $p$-value of 0.007 (less than 5\%) in Table 3 indicates that the variable under consideration is significant to influence the dependent variable. This result implies that employers and their associations have an impact on the growth and dwarfism of the industrial relations system of Nigeria.

Table 3

The ANOVA

\begin{tabular}{llrcccc}
\hline \multicolumn{7}{c}{ ANOVA $^{\mathrm{b}}$} \\
\hline Model & & $\begin{array}{c}\text { Sum of } \\
\text { Squares }\end{array}$ & Df & $\begin{array}{c}\text { Mean } \\
\text { Square }\end{array}$ & F & Sig. \\
\hline 1 & Regression & 8.884 & 1 & 8.884 & 7.510 & $0.007^{\mathrm{a}}$ \\
& Residual & 114.752 & 97 & 1.183 & & \\
& Total & 123.636 & 98 & & & \\
\hline
\end{tabular}

a. Predictors: (Constant), Stringent_policies_principles_promugalted_by_employer

b. Dependent Variable: Employers_interaction_with_subordinates_cover_organisation

Table 4 shows the estimated regression equation. The coefficient of 'stringent_policies' is statistically significant because p-value (0.007) is less than 5 per cent. It indicates that employers have a significant impact on the growth and dwarfism of the industrial relations system of Nigeria. Based on the result, the null hypothesis is rejected. In contrast, the alternative hypothesis which states that employers or their associations have an impact on the growth and dwarfism of industrial relations system of Nigeria is accepted The result indicates that if employers and their associations go up by one unit, then the rate of growth and dwarfism would also go up by 0.254 units which is significant.

Table 4

Estimated Results of Model 1

\begin{tabular}{lcccc}
\hline Variable & Coefficient & Standard Error & t-value & Sig \\
\hline Constant & 1.697 & 0.237 & 7.164 & $0.000^{* *}$ \\
YER & 0.254 & 0.093 & 2.740 & $0.007^{* *}$ \\
$\mathrm{R}^{2}=0.072$ & & & & \\
$\mathrm{D}-\mathrm{W}=2.418$ & & & & \\
\hline
\end{tabular}

Note: ** denotes statistically significance at $5 \%$ level of significance. 
$\mathrm{H}_{2}$ : $\quad$ Employees or their unions have no impact on the growth and dwarfism of Industrial relations system of Nigeria.

The $p$-value of 0.059 (Model 1) and 0.005 (Model 2) in Table 5 indicates that the variables under consideration are significant to influence the dependent variables. This test implied that a single variable of employees has an impact on the growth and dwarfism of the industrial relations system in Nigeria. Even when used together, they can still have a weak-positive influence either growth or dwarfism of the industrial relations system in Nigeria.

Table 5

The ANOVA

\begin{tabular}{llrcccc}
\hline \multicolumn{7}{c}{ ANOVA $^{\mathrm{c}}$} \\
\hline Model & & Sum of & $\mathrm{df}$ & $\begin{array}{c}\text { Mean } \\
\text { Square }\end{array}$ & $\mathrm{F}$ & Sig. \\
& & Squares & & & & \\
\hline 2 & Regression & 14.553 & 2 & 7.277 & 5.626 & $0.005^{\text {b }}$ \\
& Residual & 124.174 & 96 & 1.293 & & \\
& Total & 138.727 & 98 & & & \\
\hline
\end{tabular}

a. Predictors: (Constant), The_use_of_strike_is_the_best_instrument_that_help_ employees

b. Predictors: (Constant), The_use_of_strike_is_the_best_instrument_that_help_ employees, Labour_union_helps_in_boosting_the_level_of_interaction

c. Dependent Variable: Trade_union_helps_everyone_in_the_country_to_acquire_desires

Table 6 estimated regression equation indicates employers or their associations have an impact on the growth and dwarfism of the industrial relations system of Nigeria as evidenced by the significant coefficient (0.005). The results indicate that if employees and their unions go up by one unit, then the rate of growth and dwarfism would still be affected by 0.222 units which is significant.

Table 6

Estimated Results of Model 2

\begin{tabular}{lcccl}
\hline Variable & Coefficient & Standard Error & t-value & Sig \\
\hline Constant & 1.789 & 0.260 & 6.873 & $0.000^{* *}$ \\
YEE $_{1}$ & 0.066 & 0.080 & 0.825 & 0.411 \\
YEE $_{2}$ & 0.222 & 0.082 & 2.715 & $0.008^{* *}$ \\
\hline
\end{tabular}

$\mathrm{R}^{2}=0.105$

$\mathrm{D}-\mathrm{W}=1.990$

Note: $* *$ denotes statistically significance at $5 \%$ level of significance. 
$\mathrm{H}_{3}$ : Government has no impact on the growth and dwarfism of the industrial relations system of Nigeria.

The $p$-value of 0.000 in the ANOVA table indicates that the variables under consideration are jointly significant to influence the dependent variables. This result implies that a single variable of government mighthave an impact on the growth and dwarfism of the industrial relations system of Nigeria. Still, when used together, they can jointly influence either growth or dwarfism of the industrial relations system in Nigeria.

Table 7

The ANOVA

\begin{tabular}{|c|c|c|c|c|c|c|}
\hline \multicolumn{7}{|c|}{ ANOVA $^{c}$} \\
\hline Model & & $\begin{array}{l}\text { Sum of } \\
\text { Squares }\end{array}$ & $\mathrm{df}$ & $\begin{array}{l}\text { Mean } \\
\text { Square }\end{array}$ & $F$ & Sig. \\
\hline \multirow[t]{3}{*}{3} & Regression & 123.074 & 2 & 61.537 & 60.072 & $.000^{\mathrm{b}}$ \\
\hline & Residual & 98.341 & 96 & 1.024 & & \\
\hline & Total & 221.414 & & & & \\
\hline
\end{tabular}

a. Predictors: (Constant), External_laws_strgthen_the_relationship_among_parties

b. Predictors: (Constant), External_laws_strgthen_the_relationship_among_parties, Government_organises_platforms_where_parties_are_celebrated

c. Dependent Variable: Policies_made_by_govt_has_encourage_peace

Table 8

Estimated Results of Model 1

\begin{tabular}{llccl}
\hline Variable & Coefficient & Standard Error & t-value & \multicolumn{1}{c}{ Sig } \\
\hline Constant & -0.034 & 0.264 & -0.129 & 0.898 \\
$\mathrm{GOV}_{1}$ & 0.482 & 0.077 & 6.260 & $0.000^{* *}$ \\
$\mathrm{GOV}_{2}$ & 0.422 & 0.085 & 4.941 & $0.000^{* *}$ \\
\hline
\end{tabular}

$\mathrm{R}^{2}=0.556$

$\mathrm{D}-\mathrm{W}=2.243$

Note: ** denotes statistically significance at $5 \%$ level of significance.

Table 8 shows that the estimated coefficient of variable 2 (government) (give variable abbreviation) is statistically significant at 5 percent level. It indicates that the government have a positive impact on the growth and dwarfism of the industrial relations system of Nigeria. The results indicate that if the government intensifies its effort by facilitating industrial harmony 
then, the rate of growth and dwarfism would also go up by 0.422 units while keeping other variables constant.

Based on the analysis, the null hypothesis was rejected. In contrast, the alternative hypothesis which states that the government has an impact on the growth and dwarfism of the industrial relations system of Nigeria is accepted. The evidence is shown by the p-value of government variables to be $(0.000)$, which is less than 0.05 at 95.0 per cent cConfidence significance interval.

\section{Discussion}

In hypothesis one, the coefficient and correlations estimated regression equation indicates employers have an impact on the growth and dwarfism of the industrial relations system of Nigeria. This finding was in support of the study by Adeniji (2015) who investigated the industrial relations practices in Nigeria and Ghana. In contrast, Enenya (2013) who proposed that until an effective system of collective bargaining can be sustained among actors of industrial relations. Therefore, the growth in the industrial relations system will outweigh that of dwarfism in the system.

Similarly, the results related to hypothesis two show that employers have an impact on the growth and dwarfism of the industrial relations system of Nigeria. The findings were in tandem with the study of Olufemi (2018) who explored the reframing employment relations from the neo-pluralism perspectives. This finding, however, negates the pluralist theory of industrial relations except for the Dunlop's Structure theory of industrial relation who seeks to provide analytical tools to interpret and gain the widest possible understanding of those actors.

The coefficient estimated regression equation in hypothesis three indicates that the government has a positive impact on the growth and dwarfism of the industrial relations system of Nigeria. It was evident in the study by Okaka and Eriaguna (2011) who examined the government agents in the Nigerian industrial relations system.

\section{Recommendations}

A system of joint committees should be established by the employer in both private and public sector organisations to ensure that an environment of psychological participation is created. This ensures that all workers engage in the decision making and establish and restructure an efficient 
contact mechanism. That will curb the conflicting loopholes in Nigeria's industrial relations systems that hinder industrial harmony. Similarly, a labour-management mediation commission should be set up to deal with all workplace problems directly and prepare paths for alternate conflict settlement options to prevent incessant strike activities. Finally, the action by the government is necessary to rectify the inauspicious interventions and offer a long-lasting solution to the shortcomings in the structure of industrial relations in Nigeria. This can be achieved by ensuring that every industry located in the country processes and implements policies and laws. The practical assumption is that external laws outside the industry are required to reinforce the interaction between the parties in industrial relations; these laws should be checked and re-modified by the actors to change their interactions.

\section{Conclusion}

The study has discovered the growths and dwarfism of Nigeria's structure of industrial relations through the influence of the actors in industrial relations. If aid is given to these actors through support, it will ensure and develop functional industrial democracy in the country. This will create an atmosphere that encourages the participation of workers and enhances mutual agreement among the parties. A sound structure of labour relations will make a significant difference to economic growth and prosperity. Thus, healthy and harmonious labour relations build a sense of belonging and cohesiveness among the workers as well as a comfortable atmosphere that will lead to less labour strife, conflicts and disagreements that will ensure productivity in the long run.

\section{Acknowledgement}

This research received no specific grant from any funding agency.

\section{References}

Abdullahi, S. (2014). Industrial relations. Lagos city: National Open University of Nigeria Press.

Adebiyi, D. (1985). The face of Nigeria's industrial relations system. Mediterranean Journal of Social Sciences, 1(2), 23-100.

Adeniji, M. A. (2015). An analysis of industrial relations practice in Nigeria and Ghana (Similarities and differences in their systems). Global Journal of Research In Engineering, 2(3), 145 
Northrub, J. P. (2018). Government intervention in industrial relations: Issues and problems. International Journal of Labour and Trade Unionism 3(4), 16-29.

Akintayo, M., \& Adeyeye, O. J. (2012). Government policy and the collective bargaining process in Nigeria. available on http//:researchgate.com/ government_policy

Ayantunji, O., \& Ayantunji, M. M. (2016). Actors in industrial relations: Competitors, collaborators or compatriots? London: Sage.

Ayogu, D. U. (2016). Managing industrial relations in federal teaching hospitals in South-East Nigeria. available online at https://sage. org/0231-B

Beckman, B., \& Jega, A. M. (1998). Scholars and democratic politics in Nigeria. Democratisation in the Third World (pp. 234-257).MUST BE NAME OF CITY HERE: Springer.

Christopher, O. C., \& Okwy, P. O. (2015). The theoretical approach to employment and industrial relations: A comparism of subsisting orthodoxies. Lagos:University of Lagos Press.

Cox, R. (1999). Approaches to the futurology of industrial relations. Institute of Labour Studies, 8, 139-164.

Dunlop, J. T. (1958). Industrial relations system. New York: Holt Reinhert and Winston

Emiọla, A. (1979). Nigerian labour law. Ibadan University Press.

Enenya, P. (2013). Recent trends in collective bargaining in Nigeria. Industrial Relations Journal, 15(4), 47-55.

Fajana, S. (2000). The functioning of the Nigerian labour market. Lagos: Labofin Limited

Fajana, S. (2005). Industrial relations in the oil industry in Nigeria. Lagos: Labofin Limited

Fajana, S. (2006). Industrial relations in Nigeria: Theory and feature. Lagos: Labofin and Company

Fajana, S. (2007). The development of industrial relations in Nigeria: 19002006. Industrial relations in Africa. London: Palgrave Macmillan, 147-161.

Fashoyin, T. (1980). Industrial relations in Nigeria: Development and practice. Longman Publishing Group.

Fashoyin, T. (1988). A model of union behaviour in Africa. Department of Industrial Relations and Personnel Management, University of Lagos,(Memeography).

Flanders, A. (1968). Collective bargaining: A theoretical analysis. British Journal of Industrial Relations, 6(1), 1-26.

Flanders, A. (1975). Management and unions: The theory and reform of industrial relations. London: Faber and Faber.

Flanders, A. \& Fox, A. (1975). Industrial relations: What is wrong with the system. Business and Management Review, 1, 40-49. 
Fox, A. (1973). Industrial relations: A social critique of pluralist ideology. Man and Organisation, 1, 185-233.

Gill, J. (2007). One approach to the teachings of industrial relations. British Journal of Industrial Relations, 4(2), 59-102.

Karl, M. (1950). Analysing industrial relations in capitalist and labour aspect. Available online at www.academia.edu/analysing_industrial_ relations

Marsh, A. I., Evans, E. O., \& Garcia, P. (1971). Workplace industrial relations in engineering: Kogan Page (Associates).

Northrup, D. (2009). Trade without rulers: Pre-colonial economic development in South-Eastern Nigeria (Oxford Studies in African Affairs).

Ogunbameru, A. O. (2004). Ogannisational dynamics. Ibadan: Spectrum Books Limited.

Okaka, E. (2005). Government intervention in industrial relations in Nigeria 1861-2004 and The Trade Union Amendment Act 2005. University of Benin (Unpublished Masters Thesis).

Okaka, E. O., \& Eriaguna, E. (2011). Government agents in Nigeria's industrial relations system. Journal of Research in National Development, 9(1), 187-192.

Olufemi, P. (2018). Reframing employment relations: The case for neopluralism. Industrial Relations Journal, 33(1), 2-19.

Oyelekan, O. \& Mojirade, W. (2013). Actors in industrial relations: Competitors, collaborators or compatriots? Interdisciplinary Journal of Contemporary Research in Business, 4(12), 90-107.

Pradip, D. K. (2015). Industrial relations: An Indian perspective. New Delhi: Kunal Books.

Praveen, C. (2015). What do employee councils do? The impact of nonunion forms of representation on trade union organisation. Industrial Relations Journal, 32(4), 313-327.

Richardson, J. H. (2013). An introduction to the study of industrial relations. London: George Allen \& Urwin.

Rose, E. D. (2008). Employment relations. London: Pearson Education Limited.

Salamon, M. (2000). Industrial relations: Theory and practice: London: Pearson Education Limited.

Shalev, M. (2010). Industrial relations theory and the comparative study of industrial relations and industrial conflict. British Journal of Industrial Relations, 18(1), 231-256.

Ubeku, A. K. (1983). Industrial relations in developing countries: The case of Nigeria: London: Springer.

Yesufu, T. M. (1984). The dynamics of industrial relations; The Nigerian experience. Lagos: University of Lagos Press. 